\title{
Pengaruh Pemberian Propolis terhadap Ekspresi INOS dan Kadar MDA pada Otak Tikus Model Cedera Otak Traumatik
}

\section{The Influence of Propolis Administration on iNOS Expression and MDA Level in Rats' Brain Model of Traumatic Brain Injury}

\author{
Ria Damayanti ${ }^{1}$, Loeki E Fitri', Mochamad Dalhar ${ }^{2}$ \\ ${ }^{1}$ Laboratorium IImu Penyakit Saraf Rumah Sakit Umum Daerah Dr. Saiful Anwar Malang \\ ${ }^{2}$ Laboratorium Parasitologi Fakultas Kedokteran Universitas Brawijaya Malang
}

\begin{abstract}
ABSTRAK
Propolis memiliki aktivitas antioksidan dan antiinflamasi yang kuat dengan menetralisir berbagai radikal bebas dalam tubuh seperti seperti ROS dan reactive nitrogen species (RNS) dan menurunkan ekspresi dari nitric oxide synthase (NOS) dan mencegah kerusakan DNA, sehingga propolis memiliki potensi sebagai alternatif terapi dalam menurunkan ekspresi iNOS dan menurunkan radikal bebas yang diukur melalui kadar MDA pada cedera otak traumatik. Penelitian ini bertujuan untuk menguji pengaruh pemberian propolis dalam berbagai dosis pada ekspresi iNOS dan MDA di otak tikus Rattus norvegicus model traumatik. Sampel dibagi menjadi 5 kelompok, yaitu: kontrol negatif, kontrol positif, kelompok model trauma dan diberi perlakuan propolis masing-masing dosis 50mg, 100mg, dan 200mg per kgBB/hari. Pada akhir penelitian, tikus dikorbankan dan dibuat preparat otak untuk menilai ekspresi iNOS dan kadar MDA. Berdasarkan hasil analisa statistik, didapatkan hubungan yang signifikan antara ekspresi iNOS dan kadar MDA otak tikus model traumatik dengan berbagai dosis propolis (secara berurutan, Kruskal Wallis $p=0,001$; ANOVA $p=0,000(p<0,05)$ ). Penelitian ini membuktikan bahwa propolis berpengaruh dalam penurunan ekspresi iNOS dan kadar MDA di otak tikus model traumatik.
\end{abstract}

Kata Kunci: Cedera otak traumatik, iNOS, MDA, propolis

\begin{abstract}
Propolis has strong antioxidant and anti-inflammatory activities. It can neutralize free radicals in human body such as ROS and reactive nitrogen species (RNS), decrease Nitric Oxide Synthase (NOS) expression, and prevent damage to the DNA, hence propolis has a potency as an alternative therapy in reducing iNOS expression and decrease free radicals measured by MDA on traumatic brain injury. This study aimed to examine the effect of various doses of propolis administration on iNOS expression and MDA levels in Rattus norvegicus rat's brain of brain traumatic model. The samples were divided into 5 groups, namely negative control, positive control, trauma model groups treated with propolis of 50mg, 100mg, and $200 \mathrm{mg} / \mathrm{kg}$ body weight per day. At the end of the study, the rats were sacrificed and brain preparations were made to assess the iNOS expression and the MDA levels. Based on statistical analysis result, there was a significant correlation between the expression of iNOS and MDA levels in the rats of traumatic brain injury model with various doses of propolis (successively, Kruskal Wallis $p=0,001 ;$ ANOVA $p=0,000(p<0,05))$. This study proved that propolis is significant in decreasing the iNOS expression and MDA levels in the the rats' brain model of traumatic brain injury.
\end{abstract}

Keywords: iNOS, MDA, propolis, traumatic brain injury

Korespondensi: Ria Damayanti. Laboratorium Ilmu Penyakit Saraf Rumah Sakit Umum Daerah Dr. Saiful Anwar Malang, Jl. Jaksa Agung Suprapto 2 Malang Jawa Timur Tel. (0341)321297Email:dr.riadamayanti@yahoo.com 


\section{PENDAHULUAN}

Cedera otak traumatik merupakan salah satu cedera kepala yang paling sering terjadi di seluruh dunia. Gangguan ini terjadi pada $2 \%$ dari seluruh populasi di dunia setiap tahunnya dan menjadi penyebab utama kematian serta kecacatan yang berat pada anak-anak dan dewasa muda (1-3). Di Indonesia sendiri, jumlah kasus terus meningkat. Data cedera kepala di Rumah Sakit Dr. Wahidin Sudirohusodo, Makasar, pada tahun 2005, 861 kasus, tahun 2006, 817 kasus dan tahun 2007, 1078 kasus. Data pada Bagian Bedah Saraf Rumah Sakit Dr. Saiful Anwar Malang tahun 2007 menunjukkan terdapat 89 pasien cedera kepala berat yang dirawat dengan angka kematian 42,7\% $(4,5)$.

Dari beberapa penelitian menunjukkan bahwa tidak semua kerusakan neuron yang berkontribusi terhadap luaran yang buruk pada cedera otak traumatik terjadi pada waktu cedera primer (6). Sebagian besar kerusakan neuron, justru diakibatkan oleh cedera otak sekunder yang terjadi melalui beberapa mekanisme. Penelitian menunjukkan bahwa pada trauma terjadi peningkatan influks kalsium menuju ke dalam sel. Proses tersebut menyebabkan terjadinya aktivasi inducible nitric oxide synthase (iNOS) yang diekspresikan terutama oleh makrofag. Enzim ini dipercaya berperan penting dalam meningkatkan risiko terjadinya cedera otak sekunder (79).

Penelitian lain menunjukkan bahwa superoksida radikal $\left(\mathrm{O}_{2}{ }^{-}\right)$diproduksi segera setelah cedera kepala traumatic (10-12). Mekanisme ini dicetuskan oleh disregulasi Ca++ yang terjadi akibat eksitotoksisitas yang dimediasi oleh glutamat post trauma. Superoksida radikal dapat berikatan dengan NO, membentuk oksidan neurotoksik yang kuat, yaitu peroksinitrit, yang berperan dalam peroksidasi lemak, disfungsi mitokondria dan kerusakan DNA. Superoksida radikal merupakan salah satu jenis Reactive Oxygen Species (ROS) yang peningkatannya dapat dideteksi dengan pengukuran kadar malondialdehide (MDA) sebagai hasil degradasi lemak tak jenuh (10-12).

Propolis adalah suatu zat yang dihasilkan lebah madu berusia 21 hari. Propolis bersifat desinfektan (anti bakteri). Propolis telah banyak dimanfaatkan oleh masyarakat, sebagai obat tradisional untuk berbagai penyakit, seperti demam berdarah, gatal-gatal, radang tenggorokan, sakit gigi dan berbagai penyakit keradangan lain $(13,14)$. Beberapa penelitian menunjukkan bahwa propolis memiliki aktivitas antibiotik, antioksidan dan antiinflamasi (15-17). Propolis dapat menekan enzim LOX dan COX selama inflamasi, menghambat pelepasan sitokin inflamasi dan meningkatkan poduksi sitokin antiinflamasi secara simultan seperti IL-10 dan IL-4 (15). Propolis juga terbukti mempunyai efek anti-inflamasi melalui hambatan produksi ROS pada tingkat transkripsi melalui penekanan aktivasi nuclear factor kappa B (NF$\kappa B)$, yang menghambat transkripsi gen sitokin proinflamasi, seperti IL-6, IL-1B dan TNF-a, dan dengan hambatan langsung pada aktivitas katalitik iNOS $(18,19)$.

Kajian di atas menunjukkan bahwa propolis memiliki potensi sebagai alternatif terapi dalam menurunkan ekspresi iNOS dan menurunkan radikal bebas pada cedera otak traumatik. Pemberian propolis diharapkan dapat mencegah komplikasi cedera sekunder yang mungkin terjadi. Penelitian ini dilakukan untuk menguji pengaruh pemberian propolis pada tikus model cedera otak traumatik.

\section{METODE}

\section{Desain Penelitian}

Penelitian ini menggunakan desain eksperimen murni (true experimental design) secara in vivo dengan Randomized post test only controlled group design pada Rattus novergicus galur Wistar. Kriteria inklusi yang digunakan adalah tikus putih Rattus novergicus, jantan, usia 6-8 minggu, berat antara 250-300gram, sehat dan aktif. Kriteria drop out adalah tikus yang sakit dan mati pada saat penelitian berlangsung. Dalam penelitian ini, terdapat tiga kelompok perlakuan dan dua kelompok kontrol, yaitu: kelompok A (kontrol negatif, tanpa trauma otak dan tanpa diberi ekstrak propolis), kelompok B (kontrol positif, model cedera otak traumatik tanpa diberi ekstrak propolis), kelompok C (model cedera otak traumatik dan diberi propolis $50 \mathrm{mg} / \mathrm{kgBB} /$ hari), kelompok D (model cedera otak traumatik dan diberikan propolis $100 \mathrm{mg} / \mathrm{kgBB} /$ hari), dan kelompok $E$ (model cedera otak traumatik dan diberikan propolis $200 \mathrm{mg} / \mathrm{kgBB} /$ hari). Perhitungan besarnya pengulangan sampel pada setiap kelompok dilakukan sesuai referensi sehingga diperoleh hasil perhitungan 3,75 sehingga hewan coba yang dibutuhkan adalah 4 ekor untuk setiap kelompok atau secara keseluruhan dibutuhkan 20 ekor tikus (20). Penelitian ini telah mendapatkan kelaikan etik oleh Komisi Etik Penelitian Kesehatan Fakultas Kedokteran Universitas Brawijaya, dengan nomor surat 387B/EC/KEPK-PPDS/07/2015.

\section{Model Cedera Otak Traumatik}

Tikus dianestesi kemudian bulu kepala dicukur dan dibersihkan dengan alkohol 70\%. Kemudian kulit kepala dibuka. Silinder besi seberat 45 gram (diameter $4 \mathrm{~mm}$ ) dijatuhkan dengan sudut $90^{\circ}$ dari ketinggian $100 \mathrm{~cm}$ sebanyak 1 kali. Benturan dilakukan dengan energi $0,5 \mathrm{~J}$ oule sesuai formula menurut Danillo yaitu $\mathrm{W}=\mathrm{F} \times \mathrm{s}=\mathrm{m}$ $\mathrm{xaxs}=45,10^{-3} \mathrm{~kg} \times 9,8 \mathrm{~m} / \mathrm{s}^{2} \times 1 \mathrm{~m}=0,441 \mathrm{~J}(21)$.

\section{Ekstraksi Propolis}

Propolis didapatkan dari peternakan lebah di Lawang Jawa Timur, dan proses ekstraksi beserta alat dan bahan didapatkan dari Laboratorium Farmakologi Universitas Brawijaya. Pada penelitian ini, tidak dilakukan uji fitokimia. Teknik ekstraksi diawali dengan pembuatan rendemen propolis dari propolis kasar. Langkah pertama adalah mengekstraksi propolis dengan etanol sebagai pelarut memakai perbandingan propolis:etanol 70\% 1:10. Alat yang digunakan yaitu Thermostirer berkecepatan 150rpm selama 4 jam dan diputar dengan bantuan Magnetic Stirrer $5 \mathrm{~cm}$. Hasilnya disaring dengan menggunakan kertas saring sehingga didapat filtrat propolis. Filtrat dipisahkan dari pelarut dengan cara penguapan dalam rotary evaporator pada suhu $\pm 70^{\circ} \mathrm{C}$ berkecepatan 2 -3rpm. Rendemen yang diperoleh tersebut kemudian diencerkan dengan E-pure dan Tween 80, yang diproduksi oleh Barnstead Thermo Scientific (22). Rendemen diencerkan dengan tujuan agar rendemen propolis yang bersifat lengket tersebut dapat lebih mudah diberikan pada hewan coba melalui metode oral. Caranya adalah rendemen propolis dihitung untuk membuat dosis lalu ditambahkan tween 80 sebagai pengemulsi dan diencerkan dengan E-pure. Alasan menggunakan $E$-pure untuk menjaga kemurnian penelitian dari kandungan kimia bahan lain yang digunakan selain 
efek propolis terhadap hewan coba. E-pure didapatkan dari hasil pemurnian akuades, dengan metode distillasi (perebusan air dan perubahan bentuk dari cair ke gas dan kembali cair lagi, sehingga bisa memisahkan air dari partikel lain seperti ion, kontaminan organik, bakteri dan pirogen), filtrasi (penyaringan dengan penyaring membran yang memiliki pori berdiameter $0,2 \mu \mathrm{m})$, ultrafiltration, reverse osmosis deionization (pemberian tekanan eksternal untuk membalikkan aliran osmotik alami, sehingga air dipaksa melalui membran semipermeabel yang mengumpulkan dan membuang partikel partike kontaminan), electrodeionization (dengan pemberian aliran listrik pada air, terjadi pemisahan $\mathrm{H}+$ dan $\mathrm{OH}-$, ion positif melalui membran kation dan ion negatif melalui membran anion, setelah garam dibentuk dan disingkirkan, ion $\mathrm{H}+$ dan $\mathrm{OH}$ - digabungkan kembali), adsorption, dan ultraviolet oxidation (oksidasi fotokimia dengan sinar UV untuk mengeliminasi sisa sisa bahan oragnaik dan mikroorganisme), dengan menggunakan peralatan khusus produk Thermo Scientific (22). Terapi propolis diberikan per-oral setiap hari selama 7 hari dengan dosis 50, 100, dan 200mg/kgBB/hari.

\section{Panen Organ Otak Sampel}

Pembedahan tikus dilakukan dengan memberikan anestesi terlebih dahulu. Anestesi diberikan dengan injeksi ketamine $44 \mathrm{mg} / \mathrm{kgBB}$ secara intramuskular. Setelah tikus dipastikan tidak sadar (tidak menunjukkan gerakan spontan), tikus dikorbankan dan dilakukan pembedahan untuk mengambil jaringan otak tikus. Hemisfer otak sisi kiri diambil dan dimasukkan kedalam botol yang telah diisi larutan formalin $10 \%$, sedangkan hemisfer kanan dimasukkan ke dalam plastik untuk dilakukan pemeriksaan MDA. Selanjutnya dilakukan pengirisan jaringan otak dan pembuatan slide dengan paraffin block (pengirisan preparat otak dan pembuatan slide dilakukan di Laboratorium Patologi Anatomi RSUD Dr. Soetomo).

\section{Pemeriksaan iNOS dengan Teknik Imunohistokimia}

Slide yang sudah dideparafinisasi ditetesi dengan $3 \% \mathrm{H}_{2} \mathrm{O}_{2}$ dalam metanol, kemudian dilakukan blocking protein. Selanjutnya, diinkubasi dengan antibodi primer, ditetesi dengan 0,25\% Triton dan dicuci dengan PBS steril. Setelah itu, slide diinkubasi antibodi primer, dengan antibodi primer NOS2, dan diinkubasikan semalam pada suhu $4^{\circ} \mathrm{C}$. Keesokan harinya, slide dicuci dengan PBS steril dan ditetesi dengan antibodi sekunder (Dako LSAB + System$H R P)$, diinkubasi dan dicuci lagi dengan PBS steril. Selanjutnya ditetesi dengan SA-HRP (Dako LSAB + System$H R P$ ) diinkubasikan dan dicuci dengan PBS steril (23).

Slide ditetesi dengan $\mathrm{DAB}$ ( $D A B$ chromogen : $D A B$ buffer $=$ 1:50)( Dako LSAB + System-HRP), diinkubasikan dan dicuci dengan PBS steril dan aquades. Setelah itu, slide ditetesi counterstain dengan Mayer's Hematoxilen diinkubasi dan dibilas dengan tap water. Selanjutnya dilakukan mounting dengan Entellan, kemudian slide dikeringanginkan dan dilakukan pengamatan dibawah mikroskop (23).

Penghitungan ekspresi iNOS dilakukan dengan "host spot method." Slide diamati dengan pembesaran 400x dan dilakukan penghitungan sel glia yang positif pada 10 lapang pandang dan dicari reratanya. Sel positif menunjukkan sitoplasma yang terwarnai coklat (23). Hasil pengamatan dikonfirmasi oleh ahli patologi anatomi dari Rumah Sakit dr Syaiful Anwar, Malang.

\section{Pemeriksaan Kadar MDA}

Teknik pemeriksaan kadar MDA yang dilakukan, sesuai dengan protokol yaitu sampel otak dihomogenisasi dengan dapar fosfat $2 \mathrm{~mL}$, dan ditambahkan EDTA $200 \mu \mathrm{l}$, asam trikloroasetat (TCA) $40 \% 250 \mu \mathrm{L}, \mathrm{HCl} 200 \mathrm{~mL}$, dan asam tiobarbiturat (TBA) 250 $\mu \mathrm{L}$. Ditambahkan aquabidest, dipanaskan $100^{\circ}$ di waterbath dan dilakukan sentrifus 3000rpm. Supernatan dilakukan pembacaan pada $\lambda 532$ $\mathrm{nm}$ dengan spektrofotometer (23).

\section{Analisis Statistik}

Data dianalisis secara statistik dengan menggunakan program analisis statistik SPSS Versi 22.0. Untuk parameter iNOS, karena data yang tidak memenuhi syarat untuk uji asumsi klasik, digunakan non parametrik, uji Kruskal-Wallis untuk membandingkan perbedaan rerata lebih dari dua kelompok, kemudian dilanjutkan dengan uji MannWhitney dan Korelasi Spearman. Pada parameter MDA, dilakukan uji parametrik one-way ANOVA, dilanjutkan dengan LSD post hoc test dan uji Korelasi Pearson. Hasil uji statistik dianggap bermakna secara statistik bila $p<0,05$.

\section{HASIL}

Pengaruh Pemberian Ekstrak Propolis terhadap Ekspresi iNOS pada Tikus Wistar Model Cedera Otak Traumatik

Pemeriksaan ekspresi iNOS dilakukan melalui pemeriksaan imunohistokimia pada sampel otak tikus wistar menggunakan mikroskop dengan pembesaran 400x. Sel yang mengekspresikan iNOS akan menunjukkan sitoplasma berwarna coklat. Sampel pemeriksaan histologi pada penelitian ini ditunjukkan pada Gambar 1. Walaupun hanya perwakilan dari 200 lapang pandang yang diperiksa, dari gambar tersebut, dapat dilihat bahwa pada kontrol negatif, tidak ada sel yang positif mengekspresikan iNOS. Sebaliknya, kontrol positif yang paling banyak menunjukkan sel yang positif mengekspresikan iNOS. Bentuk dan ukuran sitoplasma yang tercat coklat, bervariasi, namun bukan merupakan masalah yang berarti, karena untuk penilaian yang objektif yang dilakukan adalah penghitungan jumlah sel yang positif mengekspresikan INOS.

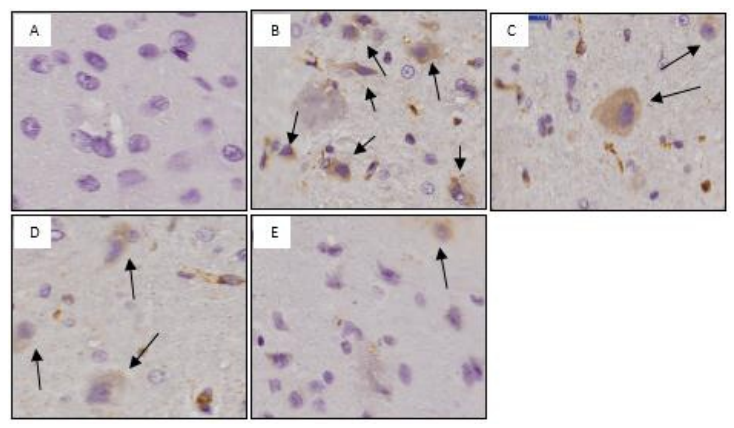

Gambar 1. Hasil pengecatan imunohistokimia sel glia kelompok kontrol dan kelompok perlakuan

Keterangan: A. Kontrol (-). B. Kontrol (+). C. Ekstrak propolis dosis 50 mg.kgbb. D. Ekstrak propolis dosis $100 \mathrm{mg} / \mathrm{kgbb}$. E. Ekstrak propolis dosis $200 \mathrm{mg} / \mathrm{kgbb}$. Tanda panah menunjukkan sel dengan ekspresi iNOS. (Ketidak seragaman, akibat pengambilan gambar secara acak)

Pengukuran dilakukan dengan cara menghitung rerata sel glia yang mengekspresikan iNOS dari 10 lapang pandang 
dari setiap slide. Nilai rerata didapatkan dari jumlah semua hasil pemeriksaan dibagi dengan banyaknya sampel pemeriksaan yang dilakukan melalui pengamatan pada 10 lapang pandang. Hasil pengamatan di bawah mikroskop, ekspresi iNOS ditampilkan pada Gambar 2.

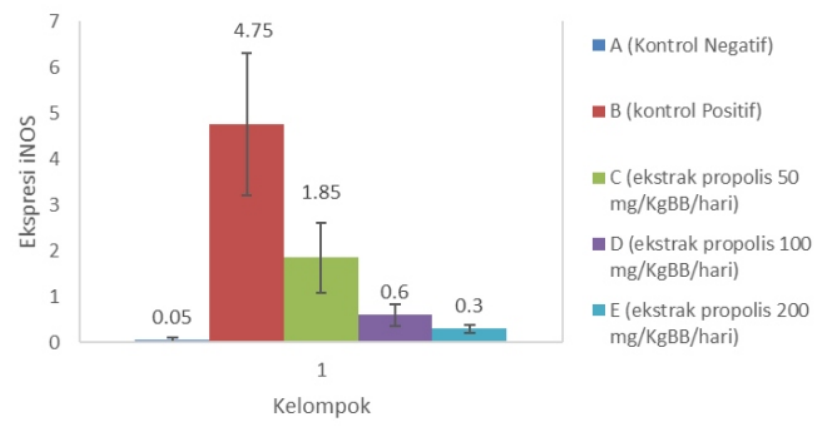

Gambar 2. Grafik histogram rata-rata ekspresi iNOS kelompok kontrol dan kelompok perlakuan

Karena tidak memenuhi uji asumsi klasik (uji normalitas Saphiro Wilk, $p=0,024$ dan uji homogenitas, $p<0,001)$, dilakukan uji analisis statistik non parametrik. Dari hasil uji Kruskal Wallis, menunjukkan nilai $p<0,001$ yang berarti ada kelompok perlakuan yang berbeda signifikan secara statistik. Analisis dilanjutkan dengan uji Mann Whitney untuk mengetahui kelompok mana yang berbeda secara signifikan. Dari hasil uji Mann Whitney, didapatkan perbedaan yang signifikan secara statistik pada semua kelompok perlakuan. Hasil uji korelasi Spearman, didapatkan hasil $p<0,001$ dan $R=-0,925$ yang menunjukkan hubungan negatif yang kuat dan signifikat secara statistik. Hal ini mengindikasikan bahwa semakin besar dosis propolis, maka terdapat kecenderungan bahwa ekpresi iNOS akan semakin menurun.

Pengaruh Pemberian Ekstrak Propolis terhadap kadar MDA pada Tikus Wistar Model Cedera Otak Traumatik

Setelah dilakukan pemeriksaan kadar MDA pada jaringan otak tikus model masing-masing kelompok perlakuan dan kontrol, didapatkan kadar MDA masing-masing kelompok sebagaimana pada Gambar 3.

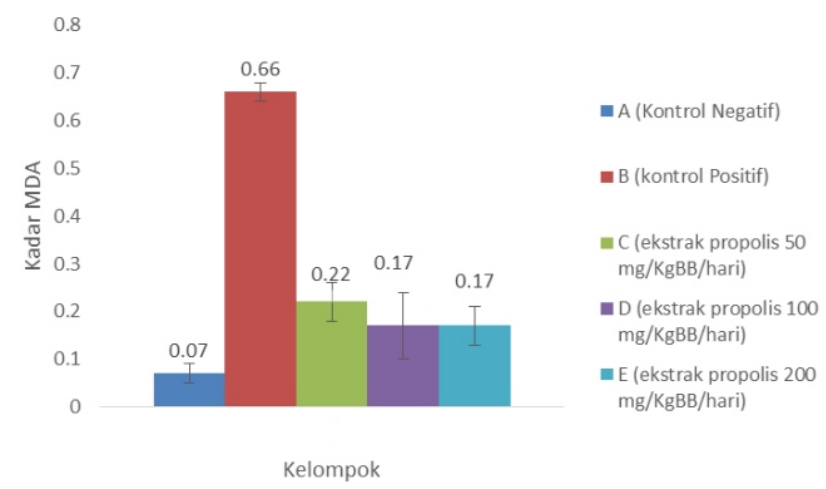

Gambar 3. histogram rata-rata kadar MDA kelompok kontrol dan kelompok perlakuan

Dari hasil uji ANOVA menunjukkan terdapat kelompok perlakuan yang berbeda secara signifikan $(p<0,001)$. Analisis dilanjutkan dengan uji Post hoc Tukey yang menunjukkan perbedaan yang bermakna pada hampir semua kelompok perlakuan kecuali pada antara kelompok perlakuan dengan pemberian ekstrak propolis (antara $C$ dan D, C dan E, serta D dan E). Dari hasil uji Korelasi Pearson $(p=0,268$ dan $R=-0,348)$ yang menunjukkan hubungan negatif dengan korelasi lemah dan signifikan secara statistik. Hal ini mengindikasikan bahwa semakin besar dosis propolis, maka terdapat kecenderungan bahwa kadar MDA akan semakin menurun.

\section{Hubungan antara ekspresi iNOS dengan kadar MDA pada} penelitian ini

Pada penelitian ini diuji hubungan antara ekspresi iNOS dan kadar MDA pada setiap kelompok penelitian. Hasil uji Korelasi Spearman menunjukkan tidak terdapat hubungan yang signiikan antara iNOS dengan kadar MDA pada semua kelompok perlakuan $(p=0,106 ; p=0,6 ; p=0,8 ; p=0,789$; $p=0,368)$.

\section{DISKUSI}

Pengaruh Pemberian Propolis terhadap Ekspresi iNOS pada Jaringan Otak Tikus Model Cedera Otak Traumatik

Mikroglia dan astrosit merupakan sel yang meregulasi respon imun di otak. Sebagai respon terhadap cedera otak traumatik, sel mikroglia dan astrosit menjadi teraktivasi dan selanjutnya melepaskan sitokin proinflamasi, radikal bebas dan eikosanoid. Nuclear factor kappa B (NF-kB) yang dihasilkan oleh mikroglia dan astrosit merupakan faktor transkripsi untuk ekspresi banyak gen-gen yang berkaitan dengan inflamasi, termasuk iNOS, COX-2, TNF- $\alpha$, IL-1 $1 \beta$, dan IL-6 (24). Sitokin proinflamasi diketahui merupakan komponen respon kekebalan alami dan didapat yang menginduksi iNOS pada mikroglia dan astrosit. Beberapa sitokin seperti IL-1 $\beta$ dan IFN- $\gamma$, secara individual mampu menginduksi iNOS pada sel glia. Sitokin lain, seperti TNF- $\alpha$ biasanya menginduksi iNOS bersama-sama dengan IL-1 $\beta$ dan IFN- $\gamma(25,26)$.

Efek dari aktivasi iNOS adalah dihasilkannya nitric oxide (NO) yang selanjutnya akan bereaksi dengan $\mathrm{O}_{2}$ untuk membentuk peroksinitrit (ONOO). Dengan adanya $\mathrm{Fe}^{2+}$, peroksinitrit akan menghasilkan radikal hidroksil, yang selanjutnya akan bereaksi dengan $\mathrm{NO}_{2}$ dengan akibat terjadinya nitrasi DNA dan protein, oksidasi DNA dan protein, serta dengan hasil akhir terjadi apoptosis sel neuron. Keadaan tersebut lebih lanjut juga akan mengaktivasi mikroglia, sehingga terbentuk kaskade inflamasi. Sekali diekspresikan, iNOS akan terus aktif sehingga berpotensi menghasilkan NO untuk periode waktu yang lama, sampai protein tersebut didegradasi $(27,28)$

Salah satu tujuan dilakukan penelitian ini adalah untuk mengetahui kemampuan ekstrak propolis sebagai antiinflamasi, seperti diketahui bahwa mediator inflamasi penting yang dihasilkan oleh sel-sel imun di otak adalah iNOS (29). Hasil penelitian ini menunjukkan bahwa pada semua kelompok perlakuan yang mendapat propolis, menunjukkan penurunan ekspresi iNOS yang signifikan dibandingkan kelompok tikus dengan cedera otak traumatik tanpa pemberian ekstrak propolis (kontrol positif). Hal ini dapat terjadi karena pada propolis terdapat kandungan flavonoid yang berperan sebagai antiinflamasi. Beberapa penelitian telah menunjukkan bahwa flavonoid mampu menurunkan ekspresi iNOS (13). Mekanisme 
molekuler flavonoid dalam menurunkan ekspresi iNOS belum diketahui secara pasti, namun diduga terjadi melalui hambatan aktivasi NF- $\kappa$ B dan signal transducer and activator of transcription 1 (STAT-1) yang merupakan faktor transkripsi penting untuk iNOS (30). Disamping itu, berdasarkan hasil penelitian juga dapat dilihat bahwa semakin tinggi dosis ekstrak propolis yang diberikan akan semakin menurunkan ekspresi iNOS pada jaringan otak tikus model cedera otak traumatik. Besarnya dosis ekstrak propolis berbanding terbalik dengan ekspresi iNOS yang dibuktikan pada penelitian ini menunjukkan bahwa kandungan flavonoid pada propolis mempunyai peranan penting sebagai antiinflamasi melalui penurunan ekspresi iNOS (30).

\section{Pengaruh Pemberian Propolis terhadap Kadar MDA pada} Jaringan Otak Tikus Model Cedera Otak Traumatik

Kandungan aktif yang diketahui terkandung dalam propolis adalah polifenol (asam fenolat, flavonoid, dan esternya), terpenoid, steroid, dan asam amino. Polifenol inilah yang memiliki peran sebagai antioksidan, dan aktivitas antioksidan ini bervariasi tergantung struktur komponen masing-masing polifenol (31-33). Mekanisme antioksidan polifenol meliputi antara lain supresi pembentukan Reactive Oxygen Spesies (ROS) dengan chelating trace element yang terlibat dalam proses pembentukan radikal bebas dan upregulasi enzim-enzim antioksidan seperti superoxide dismutase (SOD), catalase (CAT), dan glutathione peroxidase (GPx). Aktivasi enzimenzim antioksidan tersebut akan meningkatkan pembersihan dari superoxide radical. Hal ini akan mencegah terbentuknya hydroxyl radical dan lipid peroksidasi serta juga akan mencegah terbentuknya malondialdehyde (MDA) (34).

Salah satu senyawa asam fenolat dari propolis yang bekerja signifikan menghambat terbentuknya Reactive Oxygen Spesies (ROS) adalah Caffeic Acid Phenethyl Ester (CAPE). Senyawa CAPE menghambat terbentuknya Reactive Oxygen Spesies (ROS) pada level transkripsi melalui supresi aktivasi nuclear factor kappa B, dan dengan hambatan langsung pada aktivitas katalitik dari inducible nitric oxide synthase. Aktifitas antioksidan lainnya adalah dengan cara menurunkan stres oksidatif melalui kemampuannya sebagai chelating besi $(17,18,34)$.

Flavonoid juga merupakan salah satu bahan aktif sebagai antioksidan yang terkandung di dalam propolis. Kemampuan propolis sebagai antioksidan dapat menangkap radikal hidroksi dan superoksida kemudian menetralkan radikal bebas sehingga melindungi sel, mempertahankan keutuhan struktur sel dan jaringan serta dapat melindungi membran lipid terhadap reaksi yang merusak. Reaksi kimia antara flavonoid (FL-OH) dengan radikal hidroksi $(\mathrm{OH} \bullet): \mathrm{FL}-\mathrm{OH}+\mathrm{OH} \bullet \rightarrow \mathrm{H} 2 \mathrm{O}+\mathrm{FL}-$ $0 \bullet(37)$.

Penelitian Nagao menunjukkan bahwa kandungan flavonoid yaitu kelas flavonol (kaempferol, quercetin, dan myricetin) serta kelas isoflavone (genistein dan daidzein) secara in vivo memiliki kemampuan untuk menghambat aktivitas enzim xanthine oxidase. Apabila kerja enzim ini dihambat maka akan menghambat pembentukan radical superoxide sehingga tidak banyak radical superoxide yang terbentuk. Hal ini juga menunjukkan bahwa kandungan flavonoid dalam propolis dapat menghambat pembentukan Reactive Oxygen Spesies (ROS) mulai dari awal reaksi. Reaksi kimia antara flavonoid (FL-OH) dengan lipid superoxide radical ( $\mathrm{LOO} \bullet$ ): $\mathrm{LOO} \bullet+\mathrm{FL}-\mathrm{OH} \rightarrow \mathrm{LOOH}+$ FL-O• (37). Flavonoid juga menurunkan akitivitas enzim yang berpartisipasi dalam enzymatic peroxidation contohnya phospolipase A2 (PLA2), yang merupakan salah satu enzim yang menginisiasi proses peroksidasi (35).

Pada kelompok kontrol positif didapatkan kadar MDA yang paling tinggi dibandingkan kelompok lain membuktikan bahwa Reactive Oxygen Spesies (ROS) banyak diproduksi setelah cedera kepala traumatik. Senyawa ROS mendegradasi asam lemak polyunsaturated menghasilkan MDA. Tingginya kadar ROS yang diproduksi akibat cedera kepala traumatik sehingga berakibat meningkatnya kadar malondialdehyde (MDA)

Pemberian propolis mampu menurunkan kadar malondialdehyde (MDA) pada jaringan otak tikus model cedera otak traumatik. Kadar MDA pada kelompok yang diberikan ekstrak propolis lebih rendah secara signifikan jika dibandingkan dengan kadar MDA pada kelompok kontrol positif yaitu kelompok dengan cedera otak traumatik tanpa pemberian ekstrak propolis. Kandungan antioksidan yang terdapat pada propolis mampu menghambat pembentukan radikal oksigen (O2') sehingga kadar MDA pun menurun.

Semakin tinggi dosis ekstrak propolis memiliki kecenderungan untuk menurunkan kadar MDA pada jaringan otak tikus model cedera otak traumatik, namun secara statistik perbedaan tersebut tidak bermakna. Hal ini kemungkinan disebabkan rentang dosis pemberian propolis yang dilakukan pada penelitian ini masih terlalu rendah untuk menurunkan kadar MDA secara bermakna. Perlu dilakukan penelitian lebih lanjut dengan menggunakan rentang dosis ekstrak propolis yang lebih tinggi untuk menguji efektifitasnya dalam menurunkan kadar MDA secara lebih bermakna.

\section{Hubungan antara iNOS dan MDA}

Secara teori, iNOS dan MDA memiliki hubungan yang tidak langsung. Stress oksidatif akan memicu iNOS, memproduksi NO yang selanjutnya berikatan dengan radikal superoksida, menjadi peroksinitrit. Peroksinitrit yang juga merupakan radikal bebas, memicu proses peroksidase lipid, dan menghasilkan produk akhir berupa MDA. Pada penelitian ini, secara statistik tidak terdapat hubungan yang bermakna antara iNOS dengan kadar MDA pada semua kelompok perlakuan. Hal ini bisa terjadi, karena pada dasarnya MDA merupakan produk dari peroksidasi lipid dan metabolisme asam arakhidonat, yang bisa diinduksi oleh adanya radikal bebas dan inflamasi seluler. Jadi, setiap peroksinitrit bisa memicu terjadinya peroksidasi lipid, namun tidak setiap peroksidasi lipid diinduksi oleh peroksinitrit (36). Pada penelitian ini tidak dilakukan evaluasi secara klinis karena tidak ada standar penilaian khususnya.

Pada penelitian yang dilakukan oleh Zuchmann et al, dilakukan penelitian mengenai pengaruh pemberian carprofen, COX-2 inhibitor, terhadap fungsi neurologis hewan coba tikus model cedera otak traumatik, pada penelitian ini digunakan skor keparahan neurologis (neurological severity score, NSS). Kelompok yang diberi carprofen selama 7 hari, memiliki fungsi neurologis yang berbeda signifikan dengan kelompok kontrol $(p=0,008$, $p<0,005)$. Penelitian tersebut menyimpulkan bahwa obatobatan antiinflamasi memiliki pengaruh terapetik terhadap cedera otak traumatik (39). Hasil penelitian tersebut menunjukkan bahwa hambatan pada salah satu 
jaras inflamasi, mampu memberikan luaran fungsional yang bermakna. Dari hasil penelitian dapat disimpulkan bahwa pemberian ekstrak propolis pada tikus dengan

\section{DAFTAR PUSTAKA}

1. Bullock MR, Chesnut R, Ghajar J, et al. Surgical Management of Acute Subdural Hematomas. Neurosurgery. 2006; 58(3): 16-24.

2. Spiotta A, Stiefel MF, Gracias VH, et al. Brain Tissue Oxygen-directed Management and Outcome in Patients with Traumatic Brain Injury. Journal of Neurosurgery. 2010; 113(3): 571-580.

3. Ansari S, Agius S, and Debono P. Pediatric Head Injuries- a Review. Advances in Clinical Neuroscience \& Rehabilitation. 2011; 10(6): 30-35.

4. Purwati WD, Wardhani V, Mahameru G, and Istiadjid M. Penggunaan Suksinilkolin Setelah Rapid Sequence Intubation Tidak Meningkatkan Kadar Kalium Plasma Pasien dengan Cedera Kepala Berat. Jurnal Kedokteran Brawijaya. 2009; 25(2): 71-76.

5. Lisnawati, Kwandou L, Akbar M, et al. Hubungan antara Skor Cognitive Test For Delirium (CTD) dengan Outcome menurut Glasgow Outcome Scale (GOS) pada Penderita Cedera Kepala Tertutup RinganSedang. Jurnal Sains \& Teknologi Seri Ilmu-IImu Kesehatan. 2012; 2(2): 163-170.

6. Enriquez $P$ and Bullock R. Molecular and Cellular Mechanisms in the Pathophysiology of Severe Head Injury. Current Pharmaceutical Design. 2014; 10(18): 2131-2143.

7. Calabrese V, Stella AM, Butterfield DA, and Scapagnini G. Redox Regulation in Neurodegeneration and Longevity: Role of the Heme Oxygenase and HSP70 Systems in Brain Stress Tolerance. Antioxidant and Redox Signalling. 2004; 6(5): 895-913.

8. Gahm C, Holmin S, and Mathiesen T. Nitric Oxide Synthase Expression after Human Brain Contusion. Neurosurgery. 2002; 50(6): 1319-1326.

9. Jung CS, Wispel C, Zweckberger K, et al. Endogenous Nitric-Oxide Synthase Inhibitor ADMA after Acute Brain Injury. International Journal of Molecular Sciences. 2014; 15(3): 4088-103

10. Droge W. Free Radicals in the Physiological Control of Cell Function. Physiological Reviews. 2002; 82(1): 47-95.

11. Werner C and Engelhard K. Pathophysiology of Traumatic Brain Injury. British Journal of Anaesthesia. 2007; 99(1): 4-9.

12. Hansson MJ, Mansson R, Morota S, et al. Calciuminduced Generation of Reactive Oxygen Species in Brain Mitochondriais Mediated by Permeability Transition. Free Radical Biology \& Medicine. 2008; 1 ; 45(3): 284-294.

13. Bina A. Propolis: Sang Penyembuh Luar Biasa. (Online) 2008. di http://www.binaapiari.com/tipspenyembuhan/propolis-sang-penyembuh-luarbiasa/ [diakses tanggal 11 September 2014].

14. Iqbal M. Propolis Antibiotika yang Bebas di Alam. cedera otak traumatik mampu menurunkan ekspresi iNOS dan kadar MDA pada jaringan otak tikus model cedera otak traumatik.

2008. Diakses di http://rumahmadu.com/2008/ 01/propolis-antibiotika-yang-bebas.html/ [diakses tanggal 11 September 2014].

15. Borrelli F, Maffia P, Pinto L, et al. Phytochemical Compounds Involved in the Anti-inflammatory Effect of Propolis Extract. Fitoterapia. 2002; 73(1): S53-63

16. Ferreira FM, de Lima AAS, Gregio AMT, Azevedo LR, Machado MAN, and Ignacio SA. Mast Cell Population on Oral Ulcers of Rats Treated by Brazilian Propolis. Pharmacologyonline. 2006; 2: 178-189.

17. de Moura SA, Ferreira MA, Andrade SP, Reis ML, Noviello ML, and Cara DC. Brazilian Green Propolis Inhibits Inflammatory Angiogenesis in a Murine Sponge Model. Evidence-Based Complementary And Alternative Medicine. 2011; 2011: 7.

18. Wu Z, Zhu A, Takayama F, et al. Brazilian Green Propolis Suppresses the Hypoxia-Induced Neuroinflammatory Responses by Inhibiting NF-KB Activation in Microglia. Oxidative Medicine and Cellular Longevity Volume. 2013; 2013: 10

19. Marquez N, Sancho R, Macho A, Calzado MA, Fiebich $\mathrm{BL}$, and Muñoz E. Caffeic Acid Phenethyl Ester Inhibits T-Cell Activation by Targeting Both Nuclear Factor of Activated T-Cells and NF-B Transcription Factors. Journal of Pharmacology and Experimental Therapeutics. 2004; 308(3): 993-1001.

20. Istiadjid MES. Buku Ajar Etik Penelitian Kesehatan. Malang: UB Press; 2013; hal. 147-152.

21. Silva Ddos S, Brito JN, Ibiapina JO, et al. Traumatic Brain Injury. Clinical and Pathological Parameters in an Experimental Weightdrop Model. Acta Cirúrgica Brasileira. 2011; 26(2): 94-100.

22. Thermo Scientific. Thermo Scientific Waterbook, Thermo Scientific "Barnstead" Water Purification Technologies. Barnstead E-Pure. (Online). https://tools.thermofisher.com/content/sfs/brochure s/D17384 .pdf. [diakses tangal 20 Oktober 2014].

23. van der Loos C. User Protocol: Practical Guide to Multiple Staining. (Online). http://www. biotechniques.com/multimedia/archive/00074/CRIFP-Microscopy_74545a.pdf

24. Al-Dissi NM, Salhab AS, and Al-Hajj HA. Effects of Inula Viscosa Leaf Extract on Abortion and Implantation in Rats. Journal of Ethnopharmacology. 2001; 77(1): 117-121.

25. Kaltschmidt B and Kaltschmidt C. NF-kappaB in the Nervous System. Cold Spring Harbor Perspectives in Biology. 2009; 1(3): 14.

26. Meffert MK and Baltimore D. Physiological Functions for Brain NF-kappa B. Trends in Neuroscience. 2005; 28(1): 37-43.

27. Saha RN and Pahan K. Regulation of Inducible Nitric Oxide Synthase Gene in Glial Cells. Antioxidants and Redox Signaling. 2006; 8(5-6): 929-947. 
28. Kleinert H, Schwarz PM, and Forstermann U. Regulation of the Expression of Inducible Nitric Oxide Synthase. Biological Chemistry. 2003; 384(10-11): 1343-1364.

29. Won SJ, Kim DY, and Gwag BJ. Cellular and Molecular Pathways in Ischemic Neuronal Death. Journal of Biochemistry and Molecular Biology. 2002; 35(1): 6786.

30. Lin HY, Tang $\mathrm{CH}$, Chen $\mathrm{YH}$, et al. Peptidoglycan Enhances Proinflammatory Cytokine Expression Through the TLR2 Receptor, Myd88, Phosphatidylinositol 3-Kinase/AKT and NF-Kappab Pathways in BV-2 Microglia. International Immunopharmacology. 2010; 10(8): 883-891.

31. Hamalainen $M$, Nieminen $R$, Vuorela $P$, Heinonen $M$, and Moilanen E. Anti-Inflammatory Effects of Flavonoids: Genistein, Kaempferol, Quercetin, and Daidzein Inhibit STAT-1 and NF-Kb Activations, whereas Flavone, Isorhamnetin, Naringenin, and Pelargonidin Inhibit only NF-Kb Activation along with Their Inhibitory Effect on INOS Expression and NO Production in Activated Macrophages. Mediators of Inflammation. 2007; 2007: 10.

32. Popova M, Bankova VS, Butovska D, et al. Poplar Type Propolis and Analysis of Its Biologically Active Components. Honeybee Science. 2003; 24(10): 1-6.

33. Geckil H, Ates B, Durmaz G, Erdogan S, and Yilmaz I. Antioxidant, Free Radical Scavenging and Metal chelating Characteristics of Propolis. American
Journal of Biochemistry and Biotechnology. 2005; 1(1): 27-31.

34. Kumazawa Y, Kawaguchi K, and Takimoto $\mathrm{H}$. Immunomodulating Effects of Flavonoids on Acute and Chronic Inflammatory Responses Caused by Tumor Necrosis Factor Alpha. Current Pharmaceutical Design. 2006; 12(32): 4271-4279.

35. Ma ZG, Wang J, Jiang H, Liu TW, and Xie JX. Myricetin Reduces 6-hydroxydopamine-induced Dopamin Neuron Degeneration in Rats. Neuroreport. 2007; 18(11): 1181-1185.

36. Ostrowska J and Skrzydlewska E. The Biological Activity of Flavonoids. Postepy Fitoterapii. 2005; 3-4: 71-79.

37. Prasetyo DH, Listyaningsih SE, dan Guntur HA. Ekstrak Etanol Propolis Isolat Menurunkan Derajat Inflamasi dan Kadar Malondialdehid pada Serum Tikus Model Sepsis. Majalah Kedokteran Bandung. 2013; 45(3): 161-166.

38. Cornelius C, Crupi R, Calabrese V, et al. Traumatic Brain Injury: Oxidative Stress and Neuroprotection. Antioxidants \& Redox Signaling. 2013; 10; 19(8): 836853.

39. Thau-Zuchman O, Shohami E, Alexandrovich AG, Trembovler V, and Leker RR. The Anti-Inflammatory Drug Carprofen Improves Long-Term Outcome and Induces Gliogenesis after Traumatic Brain Injury. Journal of Neurotrauma. 2012; 29(2): 375-384. 